\title{
Taxonomic Composition of the Microflora (Cyanophytes and Microalgae) of Somone Lagoon (Senegal)
}

Gueye Madiop*, Ba Ngansoumana, Ngom Ablaye, Abdou Salam Ali Mohamed, Mbaye Mame Samba and Noba Kandioura

Laboratoire de Botanique - Biodiversité, Département de Biologie Végétale, Faculté des Sciences et Techniques, Université Cheikh Anta Diop, BP 5005, Dakar-Fann, Sénégal

DOI: $10.36347 / \mathrm{sajb} .2020 . \mathrm{v} 08 \mathrm{i} 07.003$

| Received: 11.07.2020 | Accepted: 18.07.2020| Published: 21.07 .2020

*Corresponding author: Gueye Madiop

Abstract

Original Research Article

This work aims to determine taxonomic composition of the microflora (cyanophytes and microalgae) of Somone Lagoon. Observation of the samples collected between March and June 2013 has allowed to list 50 species belonging to 3 phyla, 5 classes, 19 orders, 25 families and 34 genera. Bacillariophyta have the greatest species richness with $90 \%$ of the species, followed by Cyanophyta (8\%) and Euglenophyta $(2 \%)$. Bacillariaceae are the most represented family with 8 species. For the genera, these are Diploneis and Nitzschia, each with 4 species. These 50 species are new for the microflora of the Somone lagoon.

Keywords: Taxonomic composition, Microflora, cyanophytes, microalgae, Somone Lagoon, Senegal.

Copyright @ 2020: This is an open-access article distributed under the terms of the Creative Commons Attribution license which permits unrestricted use, distribution, and reproduction in any medium for non-commercial use (NonCommercial, or CC-BY-NC) provided the original author and source are credited

\section{INTRODUCTION}

The specific diversity appears essential when interested in the role of phytoplankton and periphyton in marine ecosystems. Indeed, the dynamic of the population of cyanophytes and microalgae are influenced by many environmental factors (hydroclimatic, physicochemical and biological) which act on the populations themselves, and consequently on the dynamics of species associations [1]. The determination of the taxonomic composition over a given period makes it possible to know and estimate the evolution of living conditions. Despite their relative importance at the base of trophic network, to our knowledge, there is not yet a systematic study on cyanophytes and microalgae in Somone lagoon. The objective of this work is to determine taxonomic composition of the microflora (cyanophytes and microalgae) of Somone Lagoon.

\section{MATERIALS AND METHODS \\ Presentation of the study area}

The lagoon (Figure 1) is located in the Somone watershed, $60 \mathrm{~km}$ south of Dakar, between the village of
Ndiass and Mbour City. Somone is bounded on the west by the Atlantic Ocean and the edges of the Ndiass Massif, on the north by those of the Thiès Cliff, on the east and south by the sandy plain from Tasset to Ngaparou [2]. Covering an area of $7 \mathrm{~km}^{2}$, the lagoonal-estuarine ecosystem of Somone was established as a Natural Reserve of Community Interest en 1999 [3]. The presence of the lagoon is the result of a year-round supply of marine water which maintains a very important ecological and economic mangrove. Today, water supplies from the watershed are non-existent due to the combination of several factors including the Bandia Dam. The only freshwater supplies come from precipitation and the water table [2]. Thus, the lagoonal-estuarine system of Somone is characterized by an inverse hydrological functioning where marine influences predominate. The temperature of the lagoon surface water is warmer in the wet season $\left(30^{\circ} \mathrm{C}\right.$ on average). In January, it is between 20 and $28^{\circ}$ C [3]. The overall depths are less than $1 \mathrm{~m}$. [4]. A semi-diurnal tide is exerted all year round and thus controls the immersion / emersion cycle in the ecosystem [3]. 


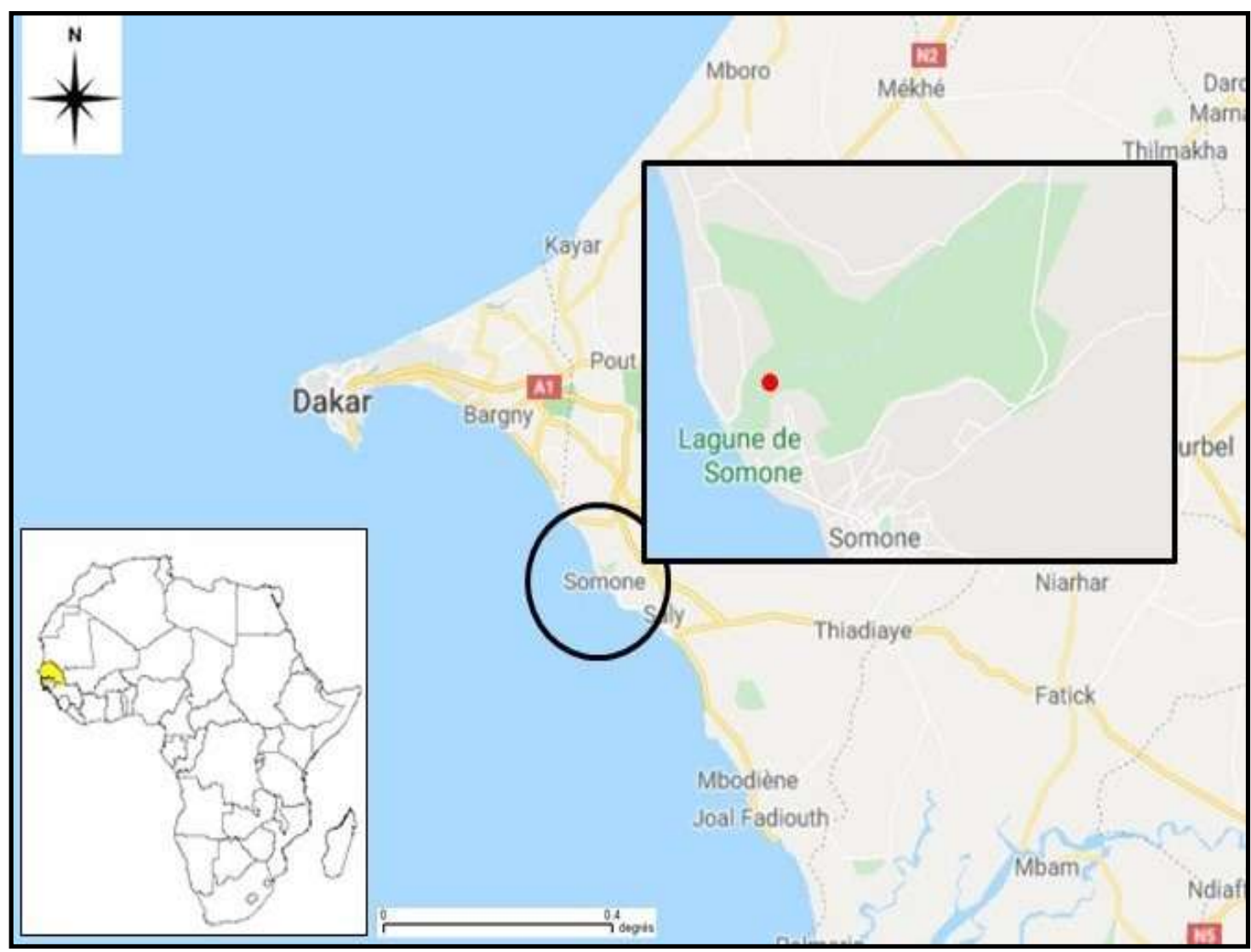

Fig-1: Location of Somone Lagoon

\section{Sampling and observation}

Samples, taken by scraping supports and using a plankton net between March and June 2013 in the lagoon $\left(14^{\circ} 29^{\prime} 49.7\right.$ " N, $017{ }^{\circ} 04^{\prime} 54.8$ " W), were observed under the microscope for the description and identification of taxa. For diatoms, a treatment for cleaning frustules was carried out.
Taxon identifications were carried out through work such as that of [5-10]. The systematic arrangement of the list was made by according to [11-14].

\section{RESULTS AND DISCUSSIONS}

Table-1: List of taxa inventoried in Somone Lagoon

\begin{tabular}{|c|c|c|c|c|}
\hline Phylum & Class & Order & Family & Species \\
\hline \multirow{4}{*}{ Cyanophyta } & \multirow{4}{*}{ Cyanophyceae } & Synechococcales & Merismopediaceae & Merismopedia $s p$ \\
\hline & & \multirow{3}{*}{ Oscillatoriales } & Oscillatoriaceae & Oscillatoria $s p 1$ \\
\hline & & & \multirow[t]{2}{*}{ Pseudanabaenaceae } & $\begin{array}{l}\text { Leptolyngbya cf. foveolarum (Rabenhorst ex } \\
\text { Gomont) }\end{array}$ \\
\hline & & & & Pseudanabaena $s p$ \\
\hline \multirow{15}{*}{ Bacillariophyta } & \multirow{8}{*}{ Coscinodiscophyceae } & \multirow{2}{*}{ Thalassiosirales } & Thalassiosiraceae & Thalassiosira eccentrica (Ehrenberg) Cleve \\
\hline & & & Stephanodiscaceae & Cyclotella stylorum Brightwell 1860 \\
\hline & & Melosirales & Melosiriaceae & Melosira crenulata (Ehr.) Kuetz \\
\hline & & Paraliales & Paraliaceae & Paralia sulcata (Ehrenberg) Cleve \\
\hline & & \multirow[b]{2}{*}{ Coscinodiscales } & \multirow[b]{2}{*}{ Coscinodiscaceae } & Coscinodiscus oculus-iridis Ehrenberg \\
\hline & & & & $\begin{array}{l}\text { Coscinodiscus oculus-iridis var. borealis } \\
\text { (Bailey) (Cleve, 1883) }\end{array}$ \\
\hline & & Triceratiales & Triceratiaceae & Odontella obtusa Kùtzing \\
\hline & & Biddulphiales & Biddulphiaceae & Biddulphia tuomeyi (J.W. Bailey) Roper 1859 \\
\hline & \multirow{7}{*}{ Fragilariophyceae } & \multirow{2}{*}{ Fragilariales } & \multirow{2}{*}{ Fragilariaceae } & Opephora pinnata var. lanceolata Boyer 1916 \\
\hline & & & & Opephora schwartzii (Grunow) Petit \\
\hline & & Rhaphoneidales & Rhaphoneidaceae & Raphoneis amphiceros var. rhombica Grun \\
\hline & & Thalassionematales & Thalassionemataceae & Thalassionema bacillare (Heiden) Kolbe \\
\hline & & \multirow{3}{*}{ Striatellales } & \multirow{3}{*}{ Striatellaceae } & Grammatophora hamulifera Kützing \\
\hline & & & & Grammatophora marina (Lyngbye) Kützing \\
\hline & & & & Grammatophora oceanica Ehrenberg 1841 \\
\hline
\end{tabular}


Gueye Madiop et al., Sch Acad J Biosci, July, 2020; 8(7): 210-213

\begin{tabular}{|c|c|c|c|c|}
\hline & & & & Achnanthes brevipes var. intermedia Agardh \\
\hline & & Achnanthales & Achnanthaceae & Achnanthes longipes f. lata Agardh \\
\hline & & Acnnanthales & & Achnanthes subconstricta (Meister) Toyoda \\
\hline & & & Cocconeidaceae & Cocconeis scutellum Ehr. \\
\hline & & & Sellaphoraceae & Fallacia forcipata (Greville) Stickle and Mann \\
\hline & & & & $\begin{array}{l}\text { Diploneis bombus (Ehrenberg) Ehrenberg ex } \\
\text { Cleve }\end{array}$ \\
\hline & & & Diploneidaceae & Diploneis elliptica (Kuetz.) $\mathrm{Cl}$. \\
\hline & & & & Diploneis gruendleri (A. Schmidt) Cleve \\
\hline & & & & Diploneis weissflogii (A. Schmidt) Cleve \\
\hline & & Naviculales & & Navicula cancellata Donkin 1873 \\
\hline & & Naviculales & Naviculaceae & $\begin{array}{l}\text { Navicula tripunctata (O.F. Müller) Bory } \\
(1822)\end{array}$ \\
\hline & & & & Navicula pennata A. S. \\
\hline & & & & Trachyneis aspera Ehr. \\
\hline & & & & Gyrosigma attenuatum (Kuetz.) Cl. \\
\hline & Bacillarionbycep & & Pleurosigmataceae & Gyrosigma balticum (Ehrenberg) Rabenhorst. \\
\hline & Bacillarıophyceae & & & Pleurosigma diverse-striatum Meister 1935 \\
\hline & & & & Amphora costata $\mathrm{Sm}$. \\
\hline & & Thalassiophysales & Catenulaceae & Amphora proteus Gregory \\
\hline & & & & Amphora turgida Gregory \\
\hline & & & & Bacillaria paxillifera (O. F. Müller) Hendey \\
\hline & & & & $\begin{array}{l}\text { Cylindrotheca closterium (Ehrenberg) } \\
\text { Reimann \& Lewin } 1964\end{array}$ \\
\hline & & & & Cylindrotheca gracilis (Breb.) Grunow \\
\hline & & Bacillariales & Bacillariaceae & Hantzschia amphioxis (Ehrenberg) Grunow \\
\hline & & & & Nitzschia coarctata Grunow \\
\hline & & & & Nitzschia obtusa (W. Smith, 1853) \\
\hline & & & & Nitzschia sigma (Kützing) W. Smith(1853) \\
\hline & & & & Nitzschia spathulata Bréb. \\
\hline & & Rhopalodiales & Rhopalodiaceae & $\begin{array}{l}\text { Rhopalodia gibba var. ventricosa (Kütz.) H. \& } \\
\text { M. Perag }\end{array}$ \\
\hline & & & & Campylodiscus thurettii Brébisson \\
\hline & & Surirellales & Surirellaceae & Surirella fastuosa (Ehrenberg) (Kützing, 1844) \\
\hline Euglenophyta & Euglenophyceae & Euglenales & Euglenaceae & Euglena spirogyra $\mathrm{Ehr}$ \\
\hline
\end{tabular}

The analysis of Table 1 show that 50 species divided into 34 genera, 25 families, 19 orders, 5 classes and 3 phyla have been inventoried. 45 of these species belong to Bacillariophyta, which represents $90 \%$ of the species richness; these species belong to 27 genera and divided into 21 families. Cyanophyta, with $8 \%$ of species richness are represented by four species belonging to three genera and three families. Euglenophyta are represented by only one species $(2 \%)$.

Bacillariaceae (Bacillariophyta) is the most representative family with 8 species; it is followed by those of Diploneidaceae and Naviculaceae with each four species. As for the genera, Diploneis and Nitzschia dominate with four species each and belong to the Bacillariophyceae Class characterized by the presence of raphe facilitating their adhesion to supports. The genera Achnanthes, Amphora, Grammatophora, Navicula each have three species.

This dominance of diatoms could be explained by their eurhyaline nature and by the fact that shallow coastal areas are generally very favourable for their growth. This is due to the speed of the mineralization and return processes in the circuit of the elementary components and to hydroclimatic factors such as salinity and especially the light and temperature [16].

\section{CONCLUSION}

This study allowed to know the taxonomic composition of the microflora (cyanophytes and microalgae) of Somone Lagoon. The 50 inventoried species belong to 3 phyla, 5 classes, 19 orders, 25 families and 34 genera. The Bacillariophyta dominate with $90 \%$ of the species richness. Bacillariaceae is the most representative family with 8 species. For the genera, Diploneis and Nitzschia each dominate with four species. These 50 species are new for the microflora of Somone Lagoon.

\section{REFERENCES}

1. Gailhard I. Analyse de la variabilité spatio-temporelle des populations microalgales côtières observées par le "Réseau de surveillance du phytoplancton et des phycotoxines" (REPHY). Université de la Méditerranée, Aix-Marseille 11. 2003; 293.

2. Diop M, Konate M. L'approche écosystémique et la gestion par bassin versant : le cas de la Somone. Diiso. 2005; 12-14. 
3. Sakho I. Evolution et fonctionnement hydro-sédimentaire de la lagune de la Somone, Petite Côte, Sénégal. Thèse de Doctorat, Université de Rouen (France) / Université Cheikh Anta Diop de Dakar (Sénégal). 2011; 252.

4. Pagès J, Leung TD. L'estuaire de la Somone: physico-chimie des eaux. Rapport "Etude des mangroves et estuaires du Sénégal Saloun et Somone ». UNESCO-EPEEC. 1984: 71-89.

5. Da Rodda C, Parodi ER. Cyanophyceae epipèlicas de la Marisma «El Cangrejal » en el estuario de Bahìa Blanca (Buenos Aires, Argentina). Bol. Soc. Argent. Bot. 2005; 40(3-4): 157-168.

6. Crispino LMB, Sant'Anna CL. Cianobactérias marinhas bentônicas de ilhas costeiras do Estado de São Paulo. Brasil Revista Brasil. Bot. 2006; 29(4): 639-656.

7. Al-Kandari M, Al-Yamani FY, Al-Rifaie K. Marine Phytoplankton Atlas of Kuwait's Waters. Lucky Printing Press, Kuwait, 2009.

8. Al-Yamani FY, Saburova MA. Illustrated guide on the benthic diatoms of Kuwait's Marine Environment. Kuwait Institute for Scientific Research. 2011; 352.

9. Lee SD, Park JS, Lee JH. Taxonomic study of the genus Achnanthes (Bacillariophyta) in Korean coastal waters. J. Ecol. Environ. 2013; 36(4): 391-406.
10. Ojeda A. Diatoms of the coastal waters of the Canary Islands. Info. Tec. Inst. Canario Cienc. Mar. 2011; (14): 219

11. Anagostidis K, Komarek J. Modern approach to the classification system of Cyanophytes, 5: Stigonematales. Algo. Studies. 1990; 59: 1-73.

12. Komarek J, Anagnostidis K. Cyanoprokaryota. 1st part Chroococcales. In Freshwater Flora of Milleleuropa, Gärtner G, Heynig H, Mollenhauer D (ed.), 19/1, Fisher, Stuttgart-Jena, Germany. 1998; 548.

13. Komarek J, Anagnostidis K. Cyanoprokaryota. 2. Teil Oscillatoriales. In Süßwasserflora von Milleleuropa, G., Gärtner, H., Heynig and D. Mollenhauer (ed.), 19/2. Fisher, Stuttgart-Jena, Germany. 2005; 759.

14. Komarek J, Anagnostidis K. Modern approach to the classification system of cyanophytes 2-Nostocales. Algological Studies. 1989; 56: 247-345

15. Round FE, Crawford R, Mann DG. The Diatoms. Morphology and biology of the genera. Cambridge University Press; 1990.

16. Paulmier G. Atlas des diatomophycées des côtes françaises et des aires océaniques adjacentes. Rapport IFREMER. 1997; 439. 